\title{
The Further Development of the International Carbon Emission Legal System under the Transition of Covid- 19
}

\author{
Yufei Liu ${ }^{*}$
}

\author{
${ }^{I}$ St. John's College \\ *Corresponding author. Email: yliu2@sjc.edu
}

\begin{abstract}
In recent years, the international society has put tremendous effort into regulating carbon dioxide emissions. While the COVID-19 pandemic had significantly impacted global energy use and created a drastic but temporary reduction in $\mathrm{CO}_{2}$ emissions, it is important to re-examine the current international legal system to produce long-lasting effects. By studying the overall structure of international law and domestic law, the problematic relationship between them can be identified. The international soft laws, compared to the domestic hard laws, have limited legal power to promote substantial achievement in environmental protection. Moreover, the difficulty in assuring equal participation and enforcement makes it even harder to maintain long-term carbon emission restrictions. Therefore, to promote connections between domestic and international law, it is fundamental to maintain the shared goal of lowering carbon emissions through the integration of international treaty laws. By bridging the gap between international and domestic laws and enhancing partnership between various regulatory bodies, the worldwide community can achieve its long-term carbon emission goals.
\end{abstract}

Keywords: carbon emission, international law, soft law, hard law

\section{INTRODUCTION}

While the emissions of carbon dioxide before the COVID-19 pandemic of 2020 were increasing consistently by $1 \%$ per year over the previous decade, the pandemic exerted a significant impact on global energy use and created a drastic but temporary reduction in $\mathrm{CO}_{2}$ emissions [1]. According to near-real-time monitoring of global $\mathrm{CO}_{2}$ emissions, the number dropped around $40 \%$ during lockdown due to lower traffic in the United States [2]. However, the environmental changes in 2020 are temporary because the global economic and energy structure remains the same. As countries recover from the pandemic and economic activities resume, global emissions would correspond to the recovery. For example, it is recorded that although global emissions decreased notably in April 2020 when many countries were in lockdown or maintaining social distancing, emissions soon began to recover in late May as economic activities resumed in China and parts of Europe. In June, the emissions were only $1.1 \%$ in 2020 than in 2019 , while in April, it was 9.7\% [3]. Therefore, it is important to reflect on the current legal structure of the environmental law system and related policy regulations to global $\mathrm{CO}_{2}$ emissions to gain insight into long-lasting improvements.

\section{PROBLEMS OF THE REGULATION OF CARBON EMISSION IN THE INTERNATIONAL COMMUNITY}

The existing difficulties of implementing effective global policies to reduce carbon emissions exist in two aspects. Firstly, the regulations are mainly determined by international laws, which are relatively weaker in establishing administrative authority than domestic laws. Secondly, the lack of authority diminishes international cooperation and effective communications between countries with various different goals.

\subsection{Imbalance Between Domestic and International Laws}

There is no doubt that multilateral negotiations have become increasingly urgent in establishing an effective system to combat climate change. However, a closer look at the interface between the international and domestic 
legal regimes can better understand the potential difficulties that prevent nations from achieving the presumed outcome. It is necessary to examine the structure and outcomes of the Paris Agreement [4]. It identifies the difficulties when nations attempt to balance participating in foreign affairs while exercising domestic policies.

Pursuing the goal of mitigating climate change and promoting global policy coherence, the 2015 Paris Agreement marks the first attempt to Unite Nations into a common goal. The agreement aims to keep "a global temperature rise this century well below 2 degrees Celsius above pre-industrial levels and to pursue efforts to limit the temperature increase even further to 1.5 degrees Celsius [2]." While the Paris Agreement is a legal instrument oversaw by the United Nations Security Council, its legal power is only manifested through a hybrid of legally binding and nonbinding provisions. The core agreements which govern the international process are binding on parties. At the same time, it leaves room for legally non-binding elements such as the intended nationally determined contributions, which may be binding at the national level if the nation extends them to domestic laws. Article Four of the agreement, for example, requires "each party to prepare, communicate and maintain successive nationally determined contributions (NDCs) that it intends to achieve." Parties can pursue domestic mitigation measures to achieve the objectives of such contributions as they see fit, while how those measures are set or accomplished is not under the UN's jurisdiction. These non-binding articles are making it difficult to actualize the cohesive response from nations, for they create gaps between the international and the domestic laws. In 2015, the United States, then a member of the agreement, only proposed a five pages long NDC which only included an overview of endeavor is willing to do and why, but it did not offer excessive detail for how to achieve these goals and what the country commits to doing on a domestic level.

In contrast, India's thirty-eight pages long NDC not only included highly detailed of its economic and environmental aspiration but also an intricately contextualized picture of its proposed methods to accomplish such goals. It is clear that although international efforts have been made to deliver a robust global response to combat climate change, the individualized, pledge-based system poses challenges for delivering actual results. There exists great inequality of devotion and action from each country. The promise of delivering a system of international cooperation and accountability that shares equal responsibility seems unrealistic. While the top ten emitters produce roughly 60 percent of total global GHG emissions, they are also among the parties least vulnerable to climate change. With that in mind, the motivation to inflict change is fundamentally uneven across nations.

\subsection{Low Intensity of International Cooperation}

Moreover, it was shown on June 1, 2017, that the mere participation of such an international agreement is not guaranteed. On that day, President Donald Trump announced the United State's intent to withdraw from the Paris Agreement, making the country relinquish its seat at the international climate change communication table [5]. Because of the predominately non-binding language of the Paris Agreement, U.S's failure to accomplish the climate obligation will not have any ramifications. Under the domestic law, the Constitution provides that the President "shall have Power, by and with the Advice and Consent of the Senate, to make Treaties, provided twothirds of the Senators present concur [6]." However, the power to withdraw from treaties is not specified by the Constitution [7]. Again, the ambiguity calls attention to examining the legal standards for international agreements and how domestic authority can establish lasting ramifications in international law context. As customary international law, "the obligation not to cause harm applies equally to all states unless the state has consistently objected to its application [8]." But such equality is not delivered under the current separation of international and domestic policies. Even in recent cases where NDC has been successfully enforced, the legislative power resided not in the international agency by within the domestic court. For example, in New Zealand, a review of the adequacy of New Zealand's NDC was called by a local law student Susan Thomson [9]. The court ruled that "the government acted unlawfully when it failed to review its 2050 mitigation target to reflect advancements in climate science." However, such a result was carried out by the national law and, more important, by domestic opposition. The failure to meet NDCs was ruled not because it was not in accordance with the UN guidelines, but because "the NDCs were made pursuant to an international agreement, the courts should not intervene in the executive branch's exercise of its foreign relations authority [10]." Therefore, despite the great endeavor of international participation in adopting NDCs, the cumulative pledges have proven to fall significantly short of the total emissions reductions needed to achieve the Paris Agreement's 2 degrees Celsius goal. Further, with one of the leading $\mathrm{CO} 2$ emitters leaving the global conversation, there is no guarantee of future cooperation between the remaining countries.

\section{ANALYSIS OF THE CAUSES OF THE EXISTING PROBLEM}

To further investigate the legal effectiveness of the current environmental laws, it is crucial to examine the pre-established dynamic of international and domestic law and the cause of imbalance as of result of their interactions. 


\subsection{Imbalance of the Basis of Legal Regulation}

In international governance, there exists a division of the hard and soft law. While the former is legally binding, the latter has no such power. Hard law "refers to legally binding obligations that are precise (or can be made precise through adjudication or the issuance of detailed regulations) that delegate authority for interpreting and implementing the law [11]." In comparison, soft law "begins once legal arrangements are weakened along with one or more of the dimensions of obligation, precision, and delegation." The distinction is manifested in the enactment stage and on how effective they are at the implementation stage. In comparison to domestic laws where administrative authorities are clearly established, centralized institutions are usually absent in the international legal system. Therefore, scholars agree that most international law is 'soft' in distinctive ways, especially as compared to most domestic law.

As shown in the previous paragraphs, the UN adopts a majority of soft laws in regulating climate issues. The Paris Agreement is not legally binding in its execution. It only requests consensus-building, which encourages voluntary and nationally determined targets. The priority of the soft law, especially seen in the UN relegation, is not that of enforcement but to create an opportunity for global cooperation and conversation. The overall aim of international cooperation is to reach a common strategic structure and "before states can cooperate to enforce an agreement, they must bargain to decide which one to implement [12]." The resulting problem is that the United Nations, given each country the liberty to bargain and develop individual approaches to resolve climate change, does not even have the power to enforce each country's basic participation. When the United States declared its retrieval from the Paris Agreement, no further impediment can be made from the Security Council, which acts as the only centralized agency. Without the judicial application, enforcement or precision, the agreement's legal authority is only reflected in articles that demand countries' communicative efforts instead of actions.

In comparison, domestic hard laws reflect greater enforcement power and precision of applications. For instance, in the United States, actually advances in clean energy use were made due to the domestic administration's effort in creating acts such as the Clean Air Act and President's Climate Action Plan.

\subsection{Imbalance of Rights Obligations of Regulatory Subjects}

While international and domestic regimes are conceptually and legally distinct, the two systems, both the international land domestic legal orders, interact only when legally enforceable mechanisms bind them together. As mentioned previously, international soft laws usually lack a leading centralized institution. Even the United Nations Security Council, which had exerted a significant impact on influencing global cooperation, does not have the power to obligate participation and execution from nations. One cannot deny the aspirations that such an entity encourages in domestic policies: guided by the international Framework Convention/ Kyoto Protocol structure, the United States had advanced greatly in refining its domestic policy on Climate change.

However, the complication of bridging the gap between the two legal systems remains for each country. To continue the United States example, international regulations and agreements, compared to those from domestic legislation and the executive branch, create greater challenges for the judiciary branch. This complication makes it exceedingly ineffective for the domestic judicial branch to examine international agreements. For "unlike domestic legislation, all international agreements, both Article II, Section 2 treaties and executive agreements, have a dual role that domestic legislation does not. They operate as compacts creating law between the United States and other sovereign powers party to the instrument, and they have a domestic legal effect through the Supremacy Clause [12]." The real difficulties reside in this latter feature and pose great challenges for the constitutional structure. All international agreements are subordinate to the Constitution. Their domestic legal legitimacy, like other actions of the executive branch, is subject to review by the courts. Therefore, the disconnect between the international and domestic law system renders the attempt to tackle ineffective and limited global climate issues.

\section{LEGAL SOLUTIONS AND SUGGESTIONS}

Since the difficulties of executing the existing carbon emission-related laws reside in the disengagement of international treaty law and domestic organic law, the solutions should also reflect improvement regarding the two.

\subsection{Promote the Convergence of Domestic Law and International Law}

To promote connections between domestic and international law, it is fundamental to maintain the shared goal of lowering carbon emissions throughout the integration of international treaty laws. Even though the individual interest of different countries, often times, may differ from the perspectives of global ambition, they should nonetheless endeavor to act in accordance with the overarching objective. Once such a goal is determined, countries should then promote changes in domestic policies by encouraging public awareness and a general understanding of the significance of making climatefriendly choices. Through public communication and 
outreach, countries can ensure better communications and cooperation between legal departments and civil society. Climate information should become transparent and accessible in order to involve the general public into the monitor of climate advancement. Public access to information such as the carbon emission data of agriculture, transportation, and other sectors can encourage the general public to establish and implement domestic environmental policies. Therefore, it is clear to recognize that in order to form effective domestic laws that act in accordance with the overall goal of international collaboration, individual countries need to enhance cooperation and participation domestically.

\subsection{Strengthen the Cooperation Between Different Regulatory Bodies}

Moreover, further integration between different legally regulatory bodies can be achieved by emphasizing the leadership of United Nations, which is the crucial legal entity to enforce cooperation between countries. It is also worth recognizing that although the issue of greenhouse gas pollution is pressing developed countries as well as developing countries, the former has more resources to adapt and address the climate resolutions than the latter. The global community should acknowledge the inevitable differences between each countries' economic as well as financial statues, while keeping in mind the overarching aim of asserting mutual benefits. It is crucial to establish this kind of mutual understanding that is founded upon a common goal across the global community. The difference between each countries' financial and political status should not hinder the common effort to build a sustainable future for the planet. Moreover, international platforms such as the United Nations should strengthen communication and cooperation within the organization. The environmental agreements should filter through all the UN's operating entities, and therefore empowering greater changes. The UN Environment Programme (UNEP), for example, has been working aside of the UN Security Council and to advocate for a more expansive environmental approach to peacebuilding and peacekeeping. Cooperation between the international organizations can consolidate the overarching environmental goal and gain more resources to actualize the ambition. Finally, individual countries should strengthen the communications between the domestic committees and the international institutions. For example, members of the European Union should effectively exchange progress and goals of individual carbon emission agenda. By enhancing the legal network on both the international and the individual level, we can bridge the gap between the two and produce an effective result.

\section{CONCLUSION}

The temporary yet inspiring result of lowering carbon emissions due to COVID-19 calls for a long-term perfection in the international environmental legal system. Through the investigation of environmental regulations and behaviors of the global community, one can recognize that the difficulties reside in the lack of enforcement power of the international soft laws as well as the integration of domestic laws. By bridging the gap between international and domestic laws and enhancing partnership between various regulatory bodies, the worldwide community can improve its carbon emission regulations. The development of a greener future for the greater society is promising if countries are dedicated to addressing the deep-rooted problem of structure in international law.

\section{REFERENCES}

[1] Peters, G.P., Andrew, R.M., Canadell, J.G. et al. Carbon dioxide emissions continue to grow amidst slowly emerging climate policies. Nat. Clim. Chang. 10, 3-6 (2020). https://doi.org/10.1038/s41558-019-0659-6

[2] B. Paital Nurture to nature via COVID-19, a selfregenerating environmental strategy of environment in global context

[3] Liu, Z., Ciais, P., Deng, Z. et al. Near-real-time monitoring of global $\mathrm{CO} 2$ emissions reveals the effects of the COVID-19 pandemic. Nat Commun 11, 5172 (2020). https://doi.org/10.1038/s41467-020-18922-7

[4] Paris Agreement on Climate Change: 195 Nations Set Path to Keep Temperature Rise Well Below 2 Degrees Celsius, UNFCCC (Dec. 13, 2014), https://unfccc. int/news/finale-cop2 1

[5] Statement by President Trump on the Paris Climate Accord (June 1, 2017) (transcript available at https://www.whitehouse.govbriefingsstatements/statement-president-trumpparis-climateaccord/ [http://perma.cc/BKG2-3HZX]).

[6] U.S. CONST. art. II, § 2, cl. 2.

[7] Hubinger, David. "Can He Do That: A Constitutional Analysis of President Trump's Withdrawal from the Paris Agreement." San Diego International Law Journal, vol. 20, no. 1, 2018, p. 127-160. HeinOnline,

[8] The Approach of the Different Drummer: The Principle of the Persistent Objector in International Law, 26 HARV. INT'L L. J. 457, 457 (1985).

[9] Rebecca Macfie, New Zealand's first climate change lawsuit rejected by High Court, NOTED 
(Nov. 17, 2019),

https://www.noted.co.nz/planet/new-zealand-s-

first-climatechange-lawsuit-rejected-by-high-

court/.

[10] Thomson v. Minister for Climate Change Issues [2017] NZHC 733 [థM 133-134] per Mallon J (N.Z.) [hereinafter Thomson v. New Zealand]

[11] Abbott, Kenneth W., and Duncan Snidal (2000). "Hard and Soft Law in International Governance," International Organization, Vol. 54, No. 3

[12] Pollack, Mark A., and Shaffer, Gregory C.. When Cooperation Fails: The International Law and Politics of Genetically Modified Foods. United Kingdom, OUP Oxford, 2009. 